\title{
Trend of Chickenpox in Jordan (2013-2020)
}

Mohammad Abdelrazzaq Alfauri ${ }^{1}$, Dr med; Adnan Ishaq Mohammad ${ }^{2}$, Dr med; Ashraf Jamil Aqel ${ }^{2}$, Dr med; Majed $\mathrm{Asad}^{2}$, Dr med

\footnotetext{
${ }^{1}$ Ministry of Health, Salt, Jordan

${ }^{2}$ Ministry of Health, Amman, Jordan
}

\section{Corresponding Author:}

Mohammad Abdelrazzaq Alfauri, Dr med

Ministry of Health

Salt

Jordan

Phone: 962776260592

Email:malfauri@gmail.com

\section{Abstract}

Background: Chickenpox is the primary infection of varicella-zoster virus (VZV), which is a highly contagious disease.

Objective: The main goal of this epidemiological descriptive study was to analyze the medical chickenpox data from 2013 to 2020 in Jordan. The aim of the study was to obtain in-depth statistics for all Jordan cities comparing the year semesters for these years, with comparisons of gender and age categories. In addition, we aimed to determine the status of the epidemiological situation in Jordan with concern of the effects of Syrian refugees and the COVID-19 epidemic.

Methods: This was an epidemiological descriptive study focusing on children under 15 years old. Data were collected based on a clinical diagnosis by doctors. Chickenpox data were obtained from the Ministry of Health as computerized and manual weekly reports from public and private health centers and hospitals. SPSS was used to statistically analyze the data.

Results: The total number of chickenpox cases reported from 2013 to 2020 in Jordan was 40,988. There was an obvious rise in cases in 2014 (19.24\%) with possible outbreaks due to the influx of Syrian refugees, whereas the lowest number of cases (2.44\%) was reported in 2020 due to the COVID-19 pandemic and associated quarantine that occurred in Jordan, especially because of closing schools and clinics. Although the total number of chickenpox cases varied from 2013 to 2020, all years showed the same seasonal distribution, with the highest numbers in the spring (especially May), at 16.12\%. Geographic distribution analysis showed that the highest numbers of cases were reported in the cities of Amman and Zarqa, with $18.15 \%$ and $12.81 \%$, respectively, according to the highest population and gatherings. In gender distribution, there was a sustained preponderance for males over females with $54.48 \%$ of the cases reported in males. The age category of 5-9 years was the most likely to be affected by this disease, accounting for $43.34 \%$ of cases. This is because these younger children are newly entering school and starting to interact with others. However, the age category of over 20 years showed the lowest number of cases, accounting for 3.98\%. There is more concern in Mafraq city (which has the greatest number of Syrian refugees), and we found that children in the age categories of 1-4 years and less than 1 year were more likely to be infected than others.

Conclusions: Our analysis showed a possible outbreak of chickenpox in 2014, and the lowest number of cases occurred in 2020. In addition, the spring season is the time with the highest number of infected cases. Chickenpox is a highly transmissible childhood disease that becomes more severe with age, and is especially prevalent in children 5-9 years of age in Jordan. Moreover, the gender distribution of cases throughout the years showed a sustained preponderance for males over females. Due to the high populations in Amman and Zarqa cities, these areas had the highest numbers of people infected with chickenpox.

(iproc 2022;8(1):e36589) doi: $\underline{10.2196 / 36589}$

\section{KEYWORDS}

chickenpox; varicella-zoster virus 
Edited by Y Khader; this is a non-peer-reviewed article. Submitted 18.01.22; accepted 19.01.22; published 07.02.22.

Please cite as:

Alfauri MA, Mohammad AI, Aqel AJ, Asad M

Trend of Chickenpox in Jordan (2013-2020)

iproc 2022;8(1):e36589

URL: https://www.iproc.org/2022/1/e36589

doi: $\underline{10.2196 / 36589}$

PMID:

(C) Mohammad Abdelrazzaq Alfauri, Adnan Ishaq Mohammad, Ashraf Jamil Aqel, Majed Asad. Originally published in Iproceedings (https://www.iproc.org), 07.02.2022. This is an open-access article distributed under the terms of the Creative Commons Attribution License (https://creativecommons.org/licenses/by/4.0/), which permits unrestricted use, distribution, and reproduction in any medium, provided the original work, first published in Iproceedings, is properly cited. The complete bibliographic information, a link to the original publication on https://www.iproc.org/, as well as this copyright and license information must be included. 